\title{
Bank customers' preferences and responses to Corporate Social Responsibility (CSR) initiatives in Ghana
}

\author{
Author: \\ Robert Ebo Hinson ${ }^{1,2}$ \\ Anne Renner ${ }^{1}$ \\ Helena van $\mathrm{Zyl}^{2}$

\section{Affiliation:} \\ ${ }^{1}$ University of Ghana \\ Business School \\ ${ }^{2}$ University of Free State \\ Business School, \\ South Africa
}

\section{Correspondence to:}

Anne Renner c/o Prof. Robert E. Hinson, Department of Marketing and Entrepreneurship, University of Ghana Business School, P.O. Box LG 78, Legon-Accra, Ghana

Tel. no.:

00233(0)244 266988

\section{E-mail:}

rhinson@ug.edu.gh

DOI:

10.15249/10-1-107

\section{Keywords:}

corporate social responsibility; Ghana; bank customers; initiatives

\section{Abstract}

The study sought to investigate Ghanaian bank customers' ranked preference for corporate social responsibility (CSR) initiatives and determine which initiative has the greatest effect on their attitudes and behaviour toward banks. A sample of 384 retail bank customers was employed in the study. The study applied a one-way MANOVA and two univariate ANOVAs. The study found that customers have the highest preference for corporate philanthropy initiatives, followed by customercentric and community volunteering initiatives. Additionally, the overall effects of CSR initiatives on customers' attitude and behavioural intentions toward bank brands are found to be significant. More specifically, the study found, using a Scheffé post-hoc test, that corporate philanthropy initiatives have the greatest effect on both attitude and behavioural intentions towards bank brands. Based on the findings, the study recommends that corporate philanthropy initiatives are the best type of CSR initiative that retail banks should apply to enhance customers' attitudes and behaviour towards their brands in Ghana.

\section{Introduction}

There is substantial agreement that CSR is concerned with societal obligations, although the nature and scope of these obligations remain uncertain (Craig Smith, 2003). Maignan and Ferrell (2004) argue that companies should only be responsible to company stakeholders, while other authors argue that companies should be responsible to society as a whole (Brown \& Dacin, 1997; Kotler \& Lee, 2005). Exactly whom companies are beholden to continues to be debated. The key theme of 
corporate social responsibility is that companies are obligated to do work for the public betterment (Safi \& Ramay, 2013).

Over the past few decades, corporate social responsibility (CSR) has been gaining prominence in organisations (Auger, Devinney, \& Louviere, 2006; Luo \& Bhattacharya, 2006; Ofori \& Hinson, 2007) and many firms now engage in one CSR activity or another. The reasons why CSR has become such an important aspect of corporate life and strategy include pressure from governments, activists, consumers and the media on organisations to be socially responsible (Porter \& Kramer, 2006) and the sometimes severe penalties that are meted out to socially irresponsible organisations. Porter and Kramer further posit that a myriad of organisations rank companies based on their CSR performance, and as such, businesses are compelled to be socially responsible.

Beyond the pressures that compel firms to engage in CSR, there is increasing evidence that links CSR to favourable stakeholder responses and firm performance indicators such as enhanced reputation, a motivated workforce, favourable consumer evaluations and increased purchases, the ability to attract potential employees and investors, and superior financial performance (Fombrun \& Shanley 1990; Albinger \& Freeman, 2000; Sen \& Bhattacharya, 2001; Sen, Bhattacharya \& Korschun, 2006; Brooks, 2010). Hence, beyond those factors that push firms into engaging in CSR (e.g. pressures and regulations), the mounting evidence of a business case for CSR may also account for the increased attention that firms are paying to CSR.

In light of these known positive effects, CSR strategies have been embraced by the international banking community. In spite of this increase in firms' attention to CSR, Guzman and Becker-Olsen (2010:211) argued that Africa is a region where there are "only sporadic efforts related to CSR and a consumer and governmental culture where CSR is not necessarily valued". Although there is mounting evidence against the assertion of 'sporadic' CSR efforts within the African region (Eweje 2006a; Visser, 2006; Ofori \& Hinson, 2007; Hinson, 2011; Hinson \& Kodua, 2012) - at least as far as countries like Nigeria, Ghana and South Africa are concerned - there seems to be little or no effort to validate or otherwise the assertion that CSR is not valued in Africa, especially from the perspective of African consumers. This study therefore contributed to filling a gap in CSR research by investigating Ghanaian consumer's preference and response to CSR.

Beyond the continental limitation of CSR consumer value research, as referred to in the preceding discussion, knowledge of consumer preference and response to CSR initiatives within the retail banking industry appears to be limited. McDonald and Lai (2011) have argued that within the retail banking sector, scant research has been carried out on customers' reactions to different CSR initiatives. Indeed, citing Rugimbana et al. (2008), McDonald and Lai (2011:51) assert that the way consumers view CSR within the banking sector is unclear due to the "surprisingly limited amount of research evaluating consumer reactions to banks' CSR activities”. In the recent past, many companies, including banks, have reduced CSR to donations (Addo, 2014). Thus, customers appeared not to select firms based on their engagement in CSR activities. 
Given that banks are important players in the financial sectors of developing economies in Africa and that banks have, for example in Ghana, been identified as adopting corporate social responsibility as a means of strengthening their reputation and improving relationships with stakeholders (Hinson, 2011), this study investigated stakeholders' preference and response to CSR from the perspective of consumers of the retail banking sector in Ghana. Specifically, the study was focused on the following:

1. Ghanaian bank customers' preference with regard to customer-centric CSR initiatives, corporate philanthropy and community volunteering;

2. the effect of customer-centric initiatives on Ghanaian banking customers' attitude towards banks than corporate philanthropy;

3. the effect of customer-centric initiatives on Ghanaian banking customers' attitude towards banks;

4. the effect of corporate philanthropy on Ghanaian bank customers' attitudes towards banks;

5. the effect of customer-centric CSR initiatives on the behavioural intentions of Ghanaian bank customers; and

6. the effect of corporate philanthropy on the behavioural intentions of Ghanaian bank customers.

\section{Carroll's typology and CSR in the African context}

Carroll (1979)'s typology of CSR is one of the most robust and widely employed in the CSR literature (Crane \& Matten, 2004; Jamali, 2008). It advances the argument that the responsibilities of corporate entities to society are fourfold, namely economic, legal, ethical and philanthropic/discretionary. Carroll (ibid.) stipulates that the economic responsibility of business entails the responsibility to produce the goods and services that society desires and to sell them at a profit. The legal responsibilities cover firms' obligation of legal compliance and 'playing by the rules of the game'. The ethical responsibilities entail society's expectations of firms in relation to their morals and business ethos, which are not stipulated in law(s), while discretionary/philanthropic responsibilities refer to purely voluntary actions motivated by a business' desire to engage in social roles that are not mandated.

In spite of its widespread adoption in the CSR literature, Carroll's conceptualisation has been criticised as not being the best model for CSR globally (see Lindgreen, Swaen, \& Campbell, 2009), and in Africa in particular (Visser, 2006). Visser (ibid) argues, for example, that Carroll's typology is largely a reflection of the views of American society on CSR (see also Dartey-Baah \& Amponsah-Tawiah, 2011) and that the order or ranking of CSR initiatives, as postulated by Carroll $(1979,1991)$, is entirely different within the African context. 
According to Carroll's (1979) typology, the least important type of CSR is what he terms philanthropic (discretionary). However, Visser (2006) contends that, in Africa, philanthropic CSR is the second most important form of CSR after economic CSR. He argues that the socio-economic needs of the African societies in which companies operate are so great that philanthropy is an expected norm and is considered the 'right thing' for business to do. Even more profound is Visser's (ibid) assertion that CSR is sometimes even equated to philanthropy within the African context.

Visser (2006) further argues that Africans are less concerned about legal CSR than their counterparts in more developed economies, since there is far less pressure for good conduct due to poorly developed legal infrastructures that lack independence, resources and administrative efficiency (see also Eweje, 2006b; Ndzibah, 2009). Visser (ibid) finally makes the assertion that, given the general level of corruption in Africa - to the extent that corrupt conduct is regarded as 'normal' - ethical CSR is least in the African mindset in respect of CSR.

A number of studies in southern Africa seem to provide support for Visser (2006)'s claims (Lindgreen et al., 2009). Enquiries into CSR in West Africa also seem to give credence to the same. For instance, Eweje (2006b:94) states that "[i] n least developed countries (LDCs), Multinational Enterprises (MNEs) are expected to provide some social services and welfare programmes in addition to their normal economic activities"; for example, they "provide education, scholarships and build roads in Nigeria; build clinics and provide drugs for AIDS/HIV patients in South Africa; and also provide medication and vaccination for malaria in Zambia". Similar assertions have been made by various other studies (Evuleocha, 2005; Frynas 2005; Amaeshi, Adi, Ogbechie, \& Amao, 2006; Eweje, 2007; Lindgreen et al., 2009). This seems also to be the case in Ghana, where WBCSD (2000) found that respondents expected firms to fill in where the government failed.

In light of the preceding discussion about the level of importance Africans attach to philanthropic CSR, this study examined the preferences of Ghanaian bank customers for social initiatives that could be classified as philanthropic/discretionary CSR. However, given existing evidence that consumers are not willing to trade the quality of firms' offerings or products for CSR activities (Guzman \& Becker-Olsen, 2010; Haigh \& Brubaker, 2010), this study also compares consumers' preferences and responses with regard to philanthropic/discretionary CSR and customer-centric CSR, i.e. corporate strategies centred on the satisfaction of customers. The study therefore employs three categories of CSR: corporate philanthropy, community volunteering and customer-centric CSR. The first two types of CSR may be classified as philanthropic/discretionary CSR, while customer-centric CSR can be classified as economic CSR, based on Caroll's (1979) definition of economic CSR discussed earlier in this paper.

A firm is said to engage in corporate philanthropy when it makes a direct contribution to a charity or a cause in the form of cash grants, donations, and/or in-kind services (Kotler \& Lee, 2005). Community volunteering, on the other hand, involves a corporation's support and encouragement of its employees, retail partners, and/or franchise members to volunteer their time to support local community organisations and causes (ibid.). For 
example, employees may volunteer their expertise, talents, ideas or physical labour in such activities as clean-up exercises in the community, organising blood donations to a hospital or breast cancer screening (Hinson, 2012). Customer-centric CSR, however, refers to all corporate strategies centred on the satisfaction of customers (Rashid, 2010b in Rashid, Abdeljawad, Ngalim \& Hassan, 2013). For example McDonald and Lai (2011) classify staff being able to handle complaints and the opening of more bank branches as customer-centric.

\section{Customers' ranked CSR preferences}

There appears to be a growing body of research into customers' preferences for/rankings of CSR - utilising various conceptualisations of social responsibility - within the CSR literature (e.g. Maignan, 2001; Maignan \& Ferrell, 2003; Auger et al., 2006). Numerous studies analysing customers' preferences with regard to CSR initiatives and their views on the nature of the responsibilities firms have towards their stakeholders have been carried out in countries spanning Europe, America and South-East Asia (e.g. Maignan \& Ferrell, 2003; Auger, et al., 2006; Pomering \& Dolnicar, 2006; McDonald \& Lai, 2011).

In Auger et al.'s (2006) cross-cultural examination of American, German, Spanish, Turkish, Indian and Korean consumers' ethical beliefs on sixteen (16) different CSR initiatives, the study respondents seemed to be more interested in issues that favoured employees, the environment and animals over issues that favoured themselves (e.g. product safety information and genetically modified materials), with customer-centric initiatives receiving low ratings across the board. However, the findings contradict those of other researchers, for example Pomering and Dolnicar (2006) and McDonald and Lai (2011), who discovered that Australian and Taiwanese bank customers prefer CSR initiatives that favour themselves as opposed to those favouring other stakeholders such as employees, the environment and the community at large. In addition, in Maignan and Ferrell's (2003) examination of French, German and American consumers, study respondents indicated that they believed a corporation's responsibility towards customers was paramount compared to its responsibility towards employees or the community.

Although customers may appreciate the psychological benefits associated with purchasing from firms whose CSR initiatives favour causes that they (i.e. the customers) care about (Bhattacharya et al., 2009), it has been contended that initiatives that provide direct benefits to customers may be preferred over those that provide indirect psychological benefits (McDonald \& Lai, 2011). In other words, customers appreciate customer-centric initiatives more than those favouring other causes and stakeholders.

Based on the preceding arguments and the fact that Visser (2006) argues that philanthropic CSR in Africa is ranked second to economic CSR (which includes production of quality goods and services) (Carroll, 1979), this study hypothesizes as follows:

- Hypothesis 1 (H1): Ghanaian bank customers prefer customer-centric CSR initiatives to corporate philanthropy and community volunteering. 
In LDCs such as Ghana, philanthropic initiatives are required of firms as part of their social responsibility (Evuleocha, 2005; Frynas, 2005; Eweje, 2006a; Eweje, 2007). Initiatives in the form of contributing corporate funds for building schools, roads and health centres, and giving money to support causes, characterised as corporate philanthropy, are preferred. The emphasis on such initiatives may be attributed to the dire need for development in all forms apparent in the lack of governmental success in development projects. To illustrate this point: in an interview at the World Business Council for Sustainable Development (WBCSD), Ghanaians stressed such issues as 'building local capacity' and 'filling in when government falls short' when asked about their perception of CSR (WBCSD, 2000).

Community volunteering initiatives usually take the form of employees taking time to help in community projects such as tree planting or clean-up exercises, and volunteering in classrooms (Kotler \& Lee, 2005). Such initiatives do not necessarily have a direct and immediate effect on the infrastructural development of society that Africans are known to favour. In light of the African emphasis on corporate philanthropy, the following hypothesis is put forward:

- Hypothesis 2 (H2): Ghanaian bank customers prefer corporate philanthropy initiatives to community volunteering initiatives.

\section{Attitudinal responses to CSR}

A number of surveys have been conducted about the effect of CSR on customers' attitudes towards different brands. The majority of these studies report a positive relationship between CSR and attitude(s) towards a firm. Citing the Cone/Roper causerelated marketing trends report, Mohr, Webb and Harris (2001) state that each year since 1993 at least $80 \%$ of people surveyed reported having a more positive image of a firm if that firm engaged in causes that they (the respondents) cared about. This is supported by numerous other studies, for example: Murray and Vogel (1997) found that respondents indicated more positive attitudes towards socially responsible firms; Sen and Bhattacharya (2001) reported that CSR had a direct positive effect on consumers' company evaluations; and Mohr et al. (2001) found that consumers expressed positive attitudes towards socially responsible firms.

On the other hand, Brown and Dacin (1997), in an evaluation of the effect of different CSR initiatives on consumer product responses, established that CSR has a positive influence on product attitudes only through company evaluations (how the consumer views the company through such things as product quality). This finding is supported by the previously discussed evidence that indicates that consumers do not favour other CSR engagements at the expense of the quality of a firm's product or service. It is therefore evident that positive consumer attitudes towards a firm and its CSR initiatives may be predicated first and foremost on the firm's ability to produce good quality products and services (e.g. Sen \& Bhattacharya, 2001; Brown \& Dacin, 1997). In other words, when customers are satisfied with the level of the product or service quality, they tend to have positive attitudes towards the firm when it engages in CSR initiatives benefiting other stakeholders. 
Customer-centric CSR initiatives may therefore be said to have the potential to provide greater levels of satisfaction (see McDonald \& Rundle-Thiele, 2008) and greater value to customers than other CSR initiatives, and that customer-centric CSR would therefore result in more positive attitudes towards the firm than other CSR initiatives. Hence hypotheses $3_{\mathrm{a}}$ and $3_{\mathrm{b}}$ :

- Hypothesis $3_{a}\left(\mathrm{H} 3_{a}\right)$ : Customer-centric initiatives have a greater effect on Ghanaian banking customers' attitude towards banks than corporate philanthropy.

- Hypothesis $3_{b}\left(\mathrm{H}_{b}\right)$ : Customer-centric initiatives have a greater effect on Ghanaian banking customers' attitude towards banks than community volunteering CSR initiatives.

Based on the arguments made on the importance of corporate philanthropy in Africa and also in Ghana, the following hypothesis is advanced:

- Hypothesis 4 (H4): Corporate philanthropy has a greater effect on Ghanaian bank customers' attitudes towards banks than community volunteering initiatives.

\section{Behavioural responses to CSR}

Some studies on different stakeholders have shown that social responsibility results in positive behavioural responses. Investors (Sen et al., 2006) and employees (Turban \& Greening, 1997; Greening \& Turban, 2000; Sen et al., 2006), for example, are reported as having a greater intention to invest and be employed, respectively, by socially-responsible firms. Customers are also reportedly more likely to purchase the products and services of socially responsible firms (see Sen et al., 2006). Additionally, two-thirds of respondents in a survey conducted by Cone/Roper (Cone Communications Press Release, 1999, as cited in Mohr et al., 2001) indicated they would switch brands and retailers to those participating in cause-related marketing. Additionally, Ross et al. (1990-91, as cited in Mohr et al., 2001) found that $49 \%$ of respondents had purchased products based on firms' support of a cause, and $54 \%$ indicated that they were more likely to switch to a new brand as a result of causerelated marketing. Creyer and Ross (1997) also conducted a survey and discovered that respondents would pay higher prices for products from an ethical company.

Additionally, consumers have cited CSR as a purchase criterion (Lewis, 2003 in Beckmann, 2007). In an interview with customers on the value received from CSR, Green and Peloza (2011) found that, for the majority of the respondents, CSR that produces functional value (direct benefits) is the leading, and in many cases, the sole driver behind integrating CSR into their decision-making processes. However, in obtaining positive behavioural responses such as purchase intentions, Berens et al. (2005, in Mandhachitara \& Poolthong, 2011) found that CSR only has a significant effect on purchase intentions when the company competency is high. This confirms that positive responses to CSR result only when the basic requirements of product and service quality are present, which McDonald and Lai (2011) and Rashid et al. (2013) classify as customer-centric CSR. Hence the following hypothesis:

- Hypothesis 5 (H5): Customer-centric CSR initiatives elicit the greatest effect on the behavioural intentions of Ghanaian bank customers. 
Given the arguments presented earlier on the importance of corporate philanthropy initiatives in the form of infrastructural development in Africa and also in Ghana, the following hypothesis is also drawn:

- Hypothesis 6 (H6): Corporate philanthropy has a greater effect on the behavioural intentions of Ghanaian bank customers than community volunteering initiatives.

\section{Methodology}

A survey was used as the method of gathering primary data from respondents, the main reason being that surveys are effective in obtaining opinions, attitudes, and descriptions, as well as in investigating cause-and-effect relationships (Ghauri \& Grønhaug, 2005).

\section{Data collection instrument}

The data collection instrument employed in this study was a semi-structured questionnaire, consisting of two parts: one pertaining to the demographic data of study respondents and the other to corporate social responsibility (CSR). A fictitious bank (First African Bank) was created for the purposes of the study and each respondent was presented with a scenario highlighting one of the three CSR initiatives (corporate philanthropy, community volunteering and customer centric CSR), which the supposed bank was purported to be engaged in. The use of fictitious companies in experimental research (see for example Brown \& Dacin, 1997; McDonald \& Lai, 2011) has proven successful in minimising any confusion due to pre-existing attitudes towards already existing companies (Groza, Pronschinske \& Walker, 2011).

Three CSR initiatives, as discussed earlier, were employed in this study: customer-centric CSR, corporate philanthropy and community volunteering. Each description of the CSR engagements of the fictitious bank had four (4) components, as McDonald and Lai (2011, citing Brown and Dacin, 1997) and Murray and Vogel (1997) assert that testing multiple combined effects of related categories of CSR initiatives is effective.

All four components making up customer-centric CSR ('employees are competent'; 'employees are efficient and reliable'; 'members of staff have very good complaints handling'; 'staff show positive attitudes and behaviour towards customers') were adapted from McDonald and Lai (2011). One component for corporate philanthropy ('building school blocks for schools in underprivileged communities') was adapted from Hinson (2012). The other three ('sponsoring needy but brilliant children to go to school'; 'donating to orphanages'; ' providing potable water to deprived communities by drilling boreholes') were adapted based on a review of two Ghanaian bank websites and one other website which gave a summary of prevailing Ghanaian bank philanthropy practices.

For community volunteering, three components were adapted from Hinson (2012): 'the bank regularly involves itself in clean-up exercises in communities'; 'the bank encourages its employees to donate part of their working hours to volunteer in classrooms'; 'the bank helps plant trees in communities'. The fourth component of community volunteering 
('the bank organises financial literacy clinics for its communities') was adapted from a website on the prevailing Ghanaian bank CSR practices.

Attitude and behavioural intentions scales were utilised in this study to examine the extent to which each CSR initiative has an effect on attitudinal and behavioural responses of bank customers. The scales contained five-point Likert items ('strongly disagree' to 'strongly agree'). The attitudinal scale consisted of three items: two ('I like my bank'; 'I feel good about my bank') were adapted from Baumann, Burton and Elliot (2007), and the third ('I am proud of my bank') from Pomering and Dolnicar (2006). For the behavioural intentions scale, which also consisted of three items, two ('I will speak positively about my bank to others'; 'I would use more of my bank's products') were adapted from Pomering and Dolnicar (ibid.), and the third ('If I had to pick a bank again, I would still choose my bank') from McDonald and Lai (2011).

\section{Sample size}

Due to the nature of the research design and analysis technique used in the study, we employed three samples (n), a sample each for the three CSR initiatives. Some scholars argue that an acceptable number of respondents per group sample $(n)$ for the method of analysis selected (MANOVA) for this study is around twenty (20) (Hair Jr., Black, Babin, Anderson \& Tatham, 2006), whereas others maintain that thirty (30) per treatment condition is adequate for detecting significant differences in group means (lacobucci, 2001 as cited in McDonald \& Lai, 2011). However, in order to obtain a statistically high observed power of at least .80 (Cohen, 1988 as cited in D’Amico, Nielands \& Zambarano, 2001; Hair et al., 2006), relatively large group sample sizes had to be obtained for each treatment group, seeing that the experiment had a low effect size. Hence each CSR initiative comprised approximately one hundred and twenty-eight (128) respondents. In sum, a sample size $(N)$ of three hundred and eighty-four (384) was obtained for the entire study.

\section{Data analysis}

This study employed a one-way multivariate analysis of variance (MANOVA) as the method of data analysis. MANOVA is an extension of its univariate form, one-way analysis of variance (one-way ANOVA). It is used to examine group differences across two or more dependent variables concurrently (Malhotra, 2007).

Multivariate tests were run to estimate the MANOVA model and to assess the overall model fit, after the examination of the MANOVA assumptions. alpha was initially set to .05; however, the results of the test did not have a satisfactory statistical power level of at least .80 (e.g. Cohen, 1988 as cited in Wilson Van Voorhis \& Morgan, 2007). This could have been attributable to the small effect size of the experiment (see Hair et al., 2006). Consequently, alpha $(\alpha)$ was set to a less stringent level of .10. In cases where effect sizes are smaller than what is desired, as it was in this case, it is permissible to decrease alpha in order to attain sufficient power levels (Hair et al., 2006). 
The results of the multivariate tests revealed a significant main effect of the independent variable (CSR initiatives) on the collective set of the dependent variables (attitude and behavioural intentions). Further univariate tests were carried out for each dependent variable to determine if there were significant differences in the dependent variables across the three groups of the independent variable. Prior to running the univariate tests, a Bonferroni adjustment of the overall acceptable level of type I error was made. The tests showed that there were indeed significant differences among the groups in their effect on attitude and then on behavioural intentions.

Although the MANOVA and the univariate ANOVA results showed that there were significant differences across the three groups of the independent variable in respect of their effects on attitude and behavioural intentions, they did not indicate exactly where the differences lay. Additionally, a statistical main effect does not guarantee that every one of the group differences is also significant (Hair et al., 2006). Hence, a Scheffé post-hoc test was conducted to examine those effects. The main reason behind the use of the Scheffé test over other post-hoc tests was that it is the most conservative with respect to type 1 error (Hair et al., 2006). The Scheffé test was a comparison between groups of the three CSR types to determine which of the differences (between the groups) were significant. Multiple combinations of the three CSR initiatives (each combination comprising two CSR initiatives) were made and the differences in means between the initiatives in each group were examined at a $90 \%$ confidence level. Inferences about CSR and customers' attitudes and behavioural intentions were made from these results.

\section{Results}

Out of the total number of 384 study respondents, $40.7 \%(n=154)$ were female and $59.3 \%$ $(n=224)$ male. The majority of respondents were aged 20 to 29 years $(63.2 \% ; n=239)$. The sample population was relatively well educated. Over $74 \%$ of the entire sample had completed tertiary education: specifically, $55.9 \%(n=213)$ had a first degree or a diploma; $16.8 \%(n=64)$ had a second, postgraduate degree; and $1.1 \%(n=7)$ had a PhD.

Reliability tests using Cronbach's alpha were carried out prior to running the one-way MANOVA. The Cronbach's alphas for the reliability of the attitude and behavioural intention(s) items were 0.813 and 0.759 , respectively. Scales with a Cronbach's alpha of 0.70 and above are deemed to be internally reliable for conclusive research (see Hair et al., 2006). Hence, the scales were internally reliable.

A one-way MANOVA revealed a significant main effect for CSR, with Roy's largest root $=0.023 ; F(2,381)=4.459 ; p=0.012 ;$ and partial eta squared $\left(\eta_{2 p}\right)=0.023$. Power to detect the effect was .849 (see Table 1). The significant multivariate main effect indicates that there was a significant difference in the means across the three CSR groups with respect to the collective linear combination of the dependent variables, attitude and behavioural intentions. In other words, each of the CSR initiatives had a significantly different effect on the multivariate combination of attitude and behavioural intentions. Hence the null hypothesis, that the means among the three CSR groups are equal, was rejected. 
Table 1: Multivariate tests

\begin{tabular}{|c|c|c|c|c|c|c|c|c|}
\hline \multicolumn{2}{|c|}{ Effect } & Value & $\mathbf{F}$ & $\begin{array}{c}\text { Hypothesis } \\
\text { df }\end{array}$ & $\begin{array}{c}\text { Error } \\
\text { df }\end{array}$ & Sigma & $\begin{array}{c}\text { Partial } \\
\eta^{2}\end{array}$ & $\begin{array}{c}\text { Observed } \\
\text { power }_{b}\end{array}$ \\
\hline Intercept & $\begin{array}{l}\text { Roy's largest } \\
\text { root }\end{array}$ & 44.894 & $8529.886_{a}$ & 2.000 & 380.000 & .000 & .978 & 1.000 \\
\hline CSR & $\begin{array}{l}\text { Roy's largest } \\
\text { root }\end{array}$ & .023 & $4.459_{c}$ & 2.000 & 381.000 & .012 & .023 & .849 \\
\hline
\end{tabular}

Given the significance of the overall multivariate test, the univariate main effects of the CSR groups on the dependent variables were examined. A Bonferroni adjustment for the two dependent variables, to hold $\alpha$ at the overall level of .10, was made prior to running the univariate tests of effects in order to reduce the chance of a type I error (Huck, 2000 as cited in Kinney, 2008). Consequently $\alpha$ was set to a more stringent level of .05 by dividing the overall alpha level of .10 by the total number of univariate tests to be conducted. The results of the univariate ANOVAs revealed that across the three CSR groups, there were significant differences in effects on attitude $(F(2,381)=3.917 ; p<0.05$; $\eta_{2 p}=0.020 ;$ power $\left._{2}=.804\right)$ and then on behavioural intentions $(F(2,381)=3.645 ; p<0.05$; $\eta_{2 p}=0.019 ;$ power $\left.=.776\right)$.

Although allowing for the rejection of the null hypothesis that group means were equal, neither the multivariate nor univariate tests indicated where the differences lay. Additionally, considering the fact that the CSR groups under consideration were above two, further one-way ANOVA post-hoc tests had to be carried out (Hair et al., 2006).

The initial evaluation of the means of responses (attitude and behavioural intentions), led to the rejection of $\mathrm{H} 1$ which held that Ghanaian bank customers prefer customer-centric CSR initiatives to corporate philanthropy and community volunteering. This is because the means for the initiatives, across both attitude and behavioural intentions, showed that customers seemed to prefer corporate philanthropy $(M=4.1510$ and $M=4.0964$ for attitude and behavioural intentions, respectively) to customer-centric CSR initiatives $(M=4.0315$ and $M=3.9685$ for attitude and behavioural intentions, respectively) and community volunteering $(M=3.9302$ and $M=3.8682$ for attitude and behavioural intentions; respectively) (see Table 2).

H2's prediction that Ghanaian bank customers prefer corporate philanthropy initiatives to community volunteering, however, seemed to be supported based on an initial evaluation of the means of both attitudinal and behavioural responses to the two CSR categories. The means suggest that, overall, corporate philanthropy $(M=4.1510$ and $M=4.0964$ for attitude and behavioural intentions, respectively) is preferred over community volunteering $(M=3.9302$ and $M=3.8682$ for attitude and behavioural intentions, respectively) (See Table 2). To further test these hypotheses and to answer the remaining hypotheses, we proceeded to perform a Scheffé post-hoc test. 
Table 2: Descriptive statistics

\begin{tabular}{c|l|c|c|c}
\hline $\begin{array}{c}\text { Dependent } \\
\text { variable }\end{array}$ & \multicolumn{1}{c}{ CSR } & Mean & \multicolumn{1}{c}{$\begin{array}{c}\text { Standard } \\
\text { deviation }\end{array}$} & N \\
\hline \multirow{4}{*}{ Attitude } & Customer-centric & 4.0315 & .60046 & 127 \\
\cline { 2 - 5 } & Corporate philanthropy & 4.1510 & .63281 & 128 \\
\cline { 2 - 5 } & Community volunteering & 3.9302 & .66363 & 129 \\
\cline { 2 - 5 } & Total & 4.0373 & .63780 & 384 \\
\hline \multirow{3}{*}{$\begin{array}{c}\text { Behavioural } \\
\text { intentions }\end{array}$} & Customer-centric & 3.9685 & .67643 & 127 \\
\cline { 2 - 5 } & Corporate philanthropy & 4.0964 & .64282 & 128 \\
\cline { 2 - 5 } & Community volunteering & 3.8682 & .71494 & 129 \\
\cline { 2 - 5 } & Total & 3.9774 & .68348 & 384 \\
\hline
\end{tabular}

The results of the Scheffé comparison, however, indicated slightly different results. Although corporate philanthropy had a greater mean $(M=4.1510 ; S D=0.63281)$ than customer-centric CSR $(M=4.0315$; $S D=0.60046)$, indicating a slightly higher effect of corporate philanthropy on attitude than customer-centric CSR at a $90 \%$ confidence level, this difference was insignificant at a p-value of 0.322 , as indicated in Table 3 . Thus $\mathrm{H} 3$ a's prediction that customer-centric CSR would have a greater effect on attitude than corporate philanthropy was rejected. Respondents had more positive attitudes to the bank in response to corporate philanthropy than to customer-centric CSR.

The post-hoc comparisons allowed for the acceptance of $\mathrm{H} 3_{\mathrm{b}}$. Customer-centric CSR had a greater mean than community volunteering $(M=3.9302$; $S D=0.66363)$, although the comparisons showed this difference to be insignificant $(p=.442)$. Respondents possessed slightly stronger behavioural intentions towards the bank in response to customercentric CSR than to community volunteering. Hence, customer-centric CSR generates a slightly stronger effect on Ghanaian customers' attitude than community volunteering.

$\mathrm{H} 4$ predicted that corporate philanthropy would have a greater effect on Ghanaian bank customers' attitude than would community volunteering initiatives. This was supported, as the post-hoc comparisons revealed that corporate philanthropy had a greater mean $(M=4.1510)$ than that of community volunteering $(M=3.9302)$, and the difference between the two (see Table 3) was significant ( $p=0.021)$ at $90 \%$ confidence.

According to $\mathrm{H} 5$, customer-centric CSR would have the greatest effect on behavioural intentions. Again, this was rejected. Corporate philanthropy $(M=4.0964 ; \mathrm{SD}=0.64282)$ had a slightly greater mean than did customer-centric CSR $(M=3.9685 ; \mathrm{SD}=0.67643)$, though this was not significant $(p>0.05)$. Post-hoc comparisons also revealed that corporate philanthropy had a significantly higher mean than community volunteering $(M=3.8682 ; S=0.71494)$, suggesting that corporate philanthropy has a greater effect on Ghanaian bank customers' behaviour than community volunteering $(p=.027)$. Hence H6 was supported. 
Table 3: Post-hoc comparisons of CSR, attitude and behavioural intentions

\begin{tabular}{|c|c|c|c|c|c|c|c|c|}
\hline \multicolumn{9}{|c|}{ Multiple comparisons } \\
\hline \multirow{2}{*}{\multicolumn{2}{|c|}{ Dependent variable }} & \multirow{2}{*}{ (I) CSR } & \multirow{2}{*}{ (J) CSR } & \multirow{2}{*}{$\begin{array}{c}\text { Mean } \\
\text { difference } \\
(I-J)\end{array}$} & \multirow{2}{*}{$\begin{array}{c}\text { Standard } \\
\text { error }\end{array}$} & \multirow{2}{*}{ Sig } & \multicolumn{2}{|c|}{$\begin{array}{c}90 \% \text { Confidence } \\
\text { interval }\end{array}$} \\
\hline & & & & & & & $\begin{array}{l}\text { Lower } \\
\text { bound }\end{array}$ & $\begin{array}{l}\begin{array}{l}\text { Upper } \\
\text { bound }\end{array} \\
\end{array}$ \\
\hline \multirow{6}{*}{ Attitude } & \multirow{6}{*}{ Scheffé } & \multirow{2}{*}{$\begin{array}{l}\text { Customer- } \\
\text { centric }\end{array}$} & $\begin{array}{l}\text { Corporate } \\
\text { philanthropy }\end{array}$ & -.1195 & .07928 & .322 & -.2902 & .0511 \\
\hline & & & $\begin{array}{l}\text { Community } \\
\text { volunteering }\end{array}$ & .1013 & .07913 & .442 & -.0691 & .2716 \\
\hline & & \multirow{2}{*}{$\begin{array}{l}\text { Corporate } \\
\text { philanthropy }\end{array}$} & $\begin{array}{l}\text { Customer- } \\
\text { centric }\end{array}$ & .1195 & .07928 & .322 & -.0511 & .2902 \\
\hline & & & $\begin{array}{l}\text { Community } \\
\text { volunteering }\end{array}$ & $.2208^{*}$ & .07897 & .021 & .0508 & .3908 \\
\hline & & \multirow{2}{*}{$\begin{array}{l}\text { Community } \\
\text { volunteering }\end{array}$} & $\begin{array}{l}\text { Customer- } \\
\text { centric }\end{array}$ & -.1013 & .07913 & .442 & -.2716 & .0691 \\
\hline & & & $\begin{array}{l}\begin{array}{l}\text { Corporate } \\
\text { philanthropy }\end{array} \\
\end{array}$ & $-.2208^{*}$ & .07897 & .021 & -.3908 & -.0508 \\
\hline \multirow{6}{*}{$\begin{array}{l}\text { Behavioural } \\
\text { intentions }\end{array}$} & \multirow{6}{*}{ Scheffé } & \multirow{2}{*}{$\begin{array}{l}\text { Customer- } \\
\text { centric }\end{array}$} & $\begin{array}{l}\text { Corporate } \\
\text { philanthropy }\end{array}$ & -.1279 & .08502 & .324 & -.3108 & .0551 \\
\hline & & & $\begin{array}{l}\text { Community } \\
\text { volunteering }\end{array}$ & .1003 & .08485 & .498 & -.0824 & .2829 \\
\hline & & \multirow{2}{*}{$\begin{array}{l}\text { Corporate } \\
\text { philanthropy }\end{array}$} & $\begin{array}{l}\text { Customer- } \\
\text { centric }\end{array}$ & .1279 & .08502 & .324 & -.0551 & .3108 \\
\hline & & & $\begin{array}{l}\text { Community } \\
\text { volunteering }\end{array}$ & $.2281^{*}$ & .08469 & .027 & .0459 & .4104 \\
\hline & & \multirow{2}{*}{$\begin{array}{l}\text { Community } \\
\text { volunteering }\end{array}$} & $\begin{array}{l}\text { Customer- } \\
\text { centric }\end{array}$ & -.1003 & .08485 & .498 & -.2829 & .0824 \\
\hline & & & $\begin{array}{l}\text { Corporate } \\
\text { philanthropy }\end{array}$ & $-.2281^{*}$ & .08469 & .027 & -.4104 & -.0459 \\
\hline
\end{tabular}

\section{Discussion}

With regard to the first objective on customers' CSR preferences, corporate philanthropy was seen to be the most preferred CSR initiative, followed by customer-centric CSR. Community volunteering was the least preferred. These results allowed for the rejection of $\mathrm{H} 1$, i.e. that customer-centric CSR would be the most preferred initiative, yet the results permitted $\mathrm{H} 2$ to be supported, i.e. that corporate philanthropy would be more appreciated than community volunteering. The findings were quite interesting, considering that the literature shows that customers may prefer initiatives that favour themselves, such as customer-centric initiatives, over those that favour other stakeholders (see for example McDonald \& Lai, 2011; Maignan \& Ferrell, 2003). However, the results are consistent with findings from other studies conducted in Africa, such as Amaeshi et al. (2006) and Eweje (2006a; 2006b), which report a strong emphasis on philanthropy among Africans. 
This finding serves to add to the growing body of evidence about the importance of and preference for philanthropy within the African context.

As the findings revealed, corporate philanthropy had the highest mean in respect of both attitude and behavioural intentions, allowing for the rejection of $\mathrm{H} 5$ that customercentric CSR would elicit the greatest attitudinal and behavioural response from Ghanaian bank customers. However, as the Scheffé comparison revealed, the difference between corporate philanthropy and customer-centric CSR was not significant, even though philanthropy had a higher mean on both dependent variables. The higher mean of corporate philanthropy may, however, be considered an indication of a stronger response to corporate philanthropy, which is consistent with other findings within the African context, as discussed earlier. Nevertheless, the non-significant $p$-value revealed through the Scheffé comparison of corporate philanthropy and customer-centric CSR initiatives also supports the existing literature that found that initiatives which are customercentred elicit relatively high positive attitude and behavioural reactions from customers (see for example McDonald \& Lai, 2011; Pomering \& Dolnicar, 2006) and as such should form a focus point for businesses, especially in the banking sector.

\section{Conclusions and recommendations}

In this study, we investigated bank customers' preferences and response to corporate social responsibility (CSR) initiatives in an African country, Ghana. The focus of the study was to determine customers' ranked preferences for three forms of CSR: corporate philanthropy, community volunteering and customer-centric CSR, and also to determine which of these three initiatives has the greatest effect on attitude and behaviour toward bank brands. The findings of the study revealed a significant main effect for CSR on both attitude and behavioural intentions for both the MANOVA and the univariate ANOVA tests. Scheffé tests also revealed that the difference in means between corporate philanthropy and community volunteering was the only one with statistical significance. However, following McDonald and Lai (2011), the analysis of the means of the three CSR initiatives indicated a preference for corporate philanthropy, followed by customercentric CSR, and lastly community volunteering.

The results of the study therefore indicate that in selecting CSR initiatives to elicit positive attitudinal and behavioural responses from customers, banks should focus on corporate philanthropy initiatives, such as building school blocks in underprivileged communities or sponsoring needy but brilliant children to attend school. However, given the insignificant difference between the mean responses to both corporate philanthropy and customercentric CSR, banks in their quest to undertake philanthropic CSR must ensure that they also fulfil customer-centric initiatives that centre on ensuring that the basic needs of the customer are not compromised. Initiatives such as demonstrating good attitudes and behaviour towards customers and having a good complaint handling system should be pursued concurrently with corporate philanthropy. In other words, corporations ought not to ignore CSR focused on the customer whilst engaging in corporate philanthropy. 
Banks could therefore leverage on the positive effects of both corporate philanthropy and customer-centric CSR on customers' attitudes and behaviour to design initiatives that enable to them succeed in the competitive marketplace.

Community volunteering recorded the lowest mean among the three types of CSR, with a significantly lower effect on both attitude and behavioural intention in comparison to corporate philanthropy. Hence, when banks are faced with a decision between these two, corporate philanthropy should be selected over community volunteering initiatives (such as clean-up exercises and financial literacy clinics). In the event that a bank wants to embark on community volunteering initiatives such as tree-planting exercises, volunteering in community schools, or organising financial literacy workshops, the core reason for their existence, which is to cater to the needs of customers, should be fulfilled. Customer-centric CSR recorded a slightly higher mean than did community volunteering, indicating a relatively higher preference for the former over the latter. Hence if the former is not attended to, there could be dissatisfaction on the part of customers.

This study was conducted in the banking sector, and the results could hence be said to be representative or peculiar to that industry alone. Replications of this study could therefore be conducted on other industries, such as the telecommunications sector. The majority of study respondents (63.2\%) were aged between 20 and 29 years; hence results could largely be a representation of the ideologies of this age group. Other studies could be conducted, for example, on other age groups in order to determine if age has an effect on CSR perceptions and its resulting effect on attitude and behaviour.

Finally, since this study employed a one-way MANOVA, future studies could employ more complex MANOVAs, such as those with factorial designs, to determine the effect of other factors, e.g. CSR and educational qualification, or CSR and gender, on attitude and behaviour and examine their interaction effects as well.

\section{References}

Addo,C.2014. Leading socially responsible companies awarded.http://www.ghanaweb.com/GhanaHomePage/ business/Leading-Socially-Responsible-Companies-Awarded-308896 [Accessed: 8 May 2016].

Albinger, H.S. \& Freeman, S.J. 2000. Corporate social performance and attractiveness as an employer to different job seeking populations. Journal of Business Ethics, 28:243-253. DOI: 10.1023/A:1006289817941

Amaeshi, K.M., Adi, B.C., Ogbechie, C. \& Amao, O.O. 2006. Corporate social responsibility (CSR) in Nigeria: Western mimicry or indigenous practices? Journal of Corporate Citizenship, 24:83-99. DOI: 10.9774/ GLEAF.4700.2006.wi.00009

Auger, P., Devinney, T.M. \& Louviere, J.J. 2006. Using best-worst scaling methodology to investigate consumer ethical beliefs across countries. Journal of Business Ethics, 70:299-326. DOI: 10.1007/s10551-006-9112-7

Baumann, C., Burton, S. \& Elliott, G. 2007. Prediction of attitude and behavioural intentions in retail banking. International Journal of Bank Marketing, 25(2):102-116. DOI: 10.1108/02652320710728438

Beckmann, S.C. 2007. Consumers and corporate social responsibility: Matching the unmatchable? Australasian Marketing Journal, 15(1):27-36. DOI: 10.1016/S1441-3582(07)70026-5

Bhattacharya, C.B., Korschun, D. \& Sen, S. 2009. Strengthening stakeholder-company relationships through mutually beneficial corporate social responsibility initiatives. Journal of Business Ethics, 85:257-272. DOI: $10.1007 / \mathrm{s} 10551-008-9730-3$ 
Brooks, S. 2010. CSR and the strait-jacket of economic rationality. International Journal of Sociology and Social Policy, 30(11):604-617.

Brown, T.J. \& Dacin, P.A. 1997. The company and the product: Corporate associations and consumer product responses. Journal of Marketing, 61(1):68-84. DOI: 10.2307/1252190

Carroll, A.B. 1979. A three-dimensional conceptual model of corporate performance. Academy of Management Review, 4(4):497-505. DOI: 10.5465/AMR.1979.4498296

Carroll, A.B. 1991. The pyramid of corporate social responsibility: Toward the moral management of organizational stakeholders. Business Horizons, 34(4):39-48. DOI: 10.1016/0007-6813(91)90005-G

Crane, A. \& Matten, D. 2004. Business Ethics. Oxford: Oxford University Press.

Craig Smith, N. 2003. Corporate social responsibility: whether or how? California Management Review, 45(4):52-76. DOI: $10.2307 / 41166188$

Creyer, E.H. \& Ross, W.T. 1997. The influence of firm behaviour on purchase intention: Do consumers really care about business ethics? Journal of Consumer Marketing, 14(6):421-432. DOI: 10.1108/07363769710185999

D’Amico, E.J., Neilands, T.B. \& Zambarano, R. 2001. Power analysis for multivariate and repeated measures designs: A flexible approach using the SPSS MANOVA procedure. Behavior Research Methods, Instruments \& Computers, 33(4):479-484. DOI: 10.3758/BF03195405

Dartey-Baah, K. \& Amponsah-Tawiah, K. 2011. Exploring the limits of Western corporate social responsibility theories in Africa. International Journal of Business and Social Science, 2(18):126-137.

Evuleocha, S.U. 2005. Managing indigenous relations: Corporate social responsibility in a new age of activism. Corporate Communications: An International Journal, 10(4):328-340. DOI: 10.1108/13563280510630124

Eweje, G. 2006a. The role of MNEs in community development initiatives in developing countries: Corporate social responsibility at work in Nigeria and South Africa. Business and Society, 45(2):93-129. DOI: $10.1177 / 0007650305285394$

Eweje, G. 2006b. Environmental costs and responsibilities resulting from oil exploitation in developing countries: The case of the Niger Delta of Nigeria. Journal of Business Ethics, 69(1):27-56. DOI: 10.1007/ s10551-006-9067-8

Eweje, G. 2007. Multinational oil companies' CSR initiatives in Nigeria: The scepticism of stakeholders in host communities. Managerial Law, 49(5/6):218-235. DOI: 10.1108/03090550710841340

Fombrun, C. \& Shanley, M. 1990. What's in a name? Reputation building and corporate strategy. Academy of Management Journal, 33(2):233-258. DOI: 10.2307/256324

Frynas, J.G. 2005. The false developmental promise of corporate social responsibility: Evidence from multinational oil companies. International Affairs, 81(3):581-598. DOI: 10.1111/j.1468-2346.2005.00470.x

Ghauri, P. \& Grønhaug, K. 2005. Research methods in business studies: A practical guide. (3rd Edition). Harlow, England: Pearson Education Limited.

Green, T. \& Peloza, J. 2011. How does corporate social responsibility create value for consumers? Journal of Consumer Marketing, 28(1):48-56. DOI: 10.1108/07363761111101949

Greening, D.W. \& Turban, D.B. 2000. Corporate social performance as a competitive advantage in attracting a quality workforce. Business and Society, 39(3):254-280. DOI: 10.1177/000765030003900302

Groza, M.D., Pronschinske, M.R. \& Walker, M. 2011. Perceived organizational motives and consumer responses to proactive and reactive CSR. Journal of Business Ethics, 102:639-652. DOI: 10.1007/s10551011-0834-9

Guzman, F. \& Becker-Oslen, K. 2010. Strategic corporate social responsibility: A brand building tool. In: Louche, C., Idowu, S.O. \& Filho L.W. (eds). Innovative CSR from Risk Management to Value Creation. Sheffield: Greenleaf. 197-219. DOI: 10.9774/GLEAF.978-1-907643-26-2_11

Haigh, M.M. \& Brubaker, P. 2010. Examining how image restoration strategy impacts perceptions of corporate social responsibility, organization-public relationships, and source credibility. Corporate Communications: An International Journal, 15(4):453-468. DOI: 10.1108/13563281011085538 
Hair Jr., J.F., Black, W.C., Babin, B.J., Anderson, R.E. \& Tatham, R.L. 2006. Multivariate data analysis. (6th Edition). Upper Saddle River, NJ: Pearson Education, Inc.

Hinson, R.E. 2011. CSR reportage of award-winning versus non award-winning banks in Ghana. Journal of Information, Communication \& Ethics in Society, 9(2):102-115. DOI: 10.1108/14779961111148622

Hinson, R.E. 2012. Service marketing excellence. With a twist of corporate social responsibility. Accra, Ghana: Sedco.

Hinson, R.E. \& Kodua, P. 2012. Examining the marketing-corporate social responsibility nexus. International Journal of Law and Management, 54(5):332-344.

Jamali, D. 2008. A stakeholder approach to corporate social responsibility: A fresh perspective into theory and practice. Journal of Business Ethics, 82:213-231. DOI: 10.1007/s10551-007-9572-4

Kinney, D.W. 2008. Selected demographic variables, school music participation, and achievement test scores of urban middle school students. Journal of Research in Music Education, 56(2):145-161. DOI: $10.1177 / 0022429408322530$

Kotler, P. \& Lee, N. 2005. Corporate social responsibility: Doing the most for your company and your cause. Hoboken, NJ: John Wiley and Sons, Inc.

Lindgreen, A., Swaen, V. \& Campbell, T.T. 2009. Corporate social responsibility practices in developing and transitional countries: Botswana and Malawi. Journal of Business Ethics, 90(3):429-440. DOI: 10.1007/ s10551-010-0415-3

Luo, X. \& Bhattacharya, C.B. 2006. Corporate social responsibility, customer satisfaction, and market value. Journal of Marketing, 70:1-18. DOI: 10.1509/jmkg.70.4.1

Maignan, I. 2001. Consumers' perceptions of corporate social responsibilities: A cross-cultural comparison. Journal of Business Ethics, 30(1):57-72. DOI: 10.1023/A:1006433928640

Maignan, I. \& Ferrell, O.C. 2003. Nature of corporate responsibilities perspectives from American, French and German consumers. Journal of Business Research, 56:55-67. DOI: 10.1016/S0148-2963(01)00222-3

Maignan, I. \& Ferrell, O.C. 2004. Corporate social responsibility and Marketing: An integrative framework. Journal of the Academy of Marketing Science, 32(1):3-19. DOI: 10.1177/0092070303258971

Malhotra, N.K. 2007. Marketing research: An applied orientation. (6th Edition). Upper Saddle River, NJ: Pearson Education, Inc. DOI: 10.1108/S1548-6435(2007)3

Mandhachitara, R. \& Poolthong, Y. 2011. A model of customer loyalty and corporate social responsibility. Journal of Services Marketing, 25(2):122-133. DOI: 10.1108/08876041111119840

McDonald, L.M. \& Lai, C.H. 2011. Impact of corporate social responsibility initiatives on Taiwanese banking customers. International Journal of Bank Marketing, 29(1):50-63. DOI: 10.1108/02652321111101374

McDonald, L.M. \& Rundle-Thiele, S. 2008. Corporate social responsibility and bank customer satisfaction: A research agenda. International Journal of Bank Marketing, 26(3):170-182. DOI: 10.1108/02652320810864643

Mohr, L.A., Webb, D.J. \& Harris, K.E. 2001. Do consumers expect companies to be socially responsible? The impact of corporate social responsibility on buying behaviour. The Journal of Consumer Affairs, 35(1):45-72. DOI: 10.1111/j.1745-6606.2001.tb00102.x

Murray, K.B. \&Vogel, C.M. 1997. Using a hierarchy-of-effects approach to gauge the effectiveness of corporate social responsibility to generate goodwill toward the firm: Financial versus nonfinancial impacts. Journal of Business Research, 38:141-159. DOI: 10.1016/S0148-2963(96)00061-6

Ndzibah, E. 2009. CSR in Ghana? Diversity should not mean dumping. Management of Environmental Quality: An International Journal, 28(7):498-518.

Ofori, D. \& Hinson, R. 2007. Corporate social responsibility perspectives of leading firms in Ghana. Corporate Governance, 7(2):178-193. DOI: 10.1108/14720700710739813

Pomering, A. \& Dolnicar, S. 2006. Customers'sensitivity to different measures of corporate social responsibility in the Australian banking sector. 2006 Australia and New Zealand Marketing Academy Conference (ANZMAC), Brisbane, 4-6 December. http://ro.uow.edu.au/cgi/viewcontent.cgi?article $=1252 \&$ context=co mmpapers [Accessed: 13 September 2012]. 
Porter, M.E. \& Kramer, M.R. 2006. Strategy and society. The link between competitive advantage and corporate social responsibility. Harvard Business Review, December, 1-15.

Rashid, M., Abdeljawad, I., Ngalim, S.M. \& Hassan, M.K. 2013. Customer-centric corporate social responsibility: A framework for Islamic banks on ethical efficiency. Management Research Review, 36(4):359-378. DOI: 10.1108/01409171311314978

Safi, A. \& Ramay, M.I. 2013. Corporate social responsibility and consumer behaviour: A study from Pakistan. Information Management and Business Review, 5(4):194-202.

Sen, S. \& Bhattacharya, C.B. 2001. Does doing good always lead to doing better? Consumer reactions to corporate social responsibility. Journal of Marketing Research, 38(2):225-243. DOI: 10.1509/ jmkr.38.2.225.18838

Sen, S., Bhattacharya, C.B. \& Korschun, D. 2006. The role of corporate social responsibility in strengthening multiple stakeholder relationships: A field experiment. Journal of the Academy of Marketing Science, 34(2):158-166. DOI: 10.1177/0092070305284978

Turban, D.B. \& Greening, D.W. 1997. Corporate social performance and organizational attractiveness to prospective employees. Academy of Management Journal, 40(3):658-672. DOI: 10.2307/257057

Visser, W. 2006. Revisiting Carroll's CSR pyramid: An African perspective. In: Huniche, M. \& Pedersen, E.R. (eds). Corporate citizenship in developing countries: New partnership perspectives. Gylling, Denmark: Narayana Press. 29-56.

Wilson Van Voorhis, C.R. \& Morgan, B.L. 2007. Understanding power and rules of thumb for determining sample sizes. Tutorials in Quantitative Methods for Psychology, 3(2):43-50.

WBCSD (World Business Council for Sustainable Development). 2000. Corporate social responsibility: Making good business sense. WBCSD, Switzerland. 